\title{
Hurricane Risks, Health Consequences, and Response Challenges for Small Island Based Populations: Observations from the 2017 Atlantic Hurricane Season
}

\author{
James M. Shultz \\ James P. Kossin \\ J. Marshall Shepherd \\ Justine M. Ransdell \\ Rory Walshe \\ Ilan Kelman \\ Sandro Galea
}

James M. Shultz MS, PhD

Director, Center for Disaster \& Extreme Event Preparedness (DEEP Center)

Voluntary Associate Professor, Department of Public Health Sciences (DPHS)

University of Miami Miller School of Medicine

1120 NW 14 Street, Miami, Florida USA 33136

305-243-8873/305-219-9011

jshultz1@med.miami.edu

James P. Kossin PhD

NOAA's National Centers for Environmental Information

(NCEI)

Center for Weather and Climate, Madison, WI

Duty Station and Mailing Address:

NOAA Cooperative Institute for Meteorological Satellite

Studies

University of Wisconsin - Madison

1225 West Dayton St., Room 205

Madison, WI 53706 USA

6o8-265-5356 (voice) /608-262-5974 (fax)

james.kossin@noaa.gov

\author{
J. Marshall Shepherd PhD \\ UGA Athletic Association Distinguished Professor of \\ Geography and Atmospheric Sciences \\ Director, Atmospheric Sciences Program \\ University of Georgia \\ Athens, GA 30602, USA. \\ 706-542-0517 \\ marshgeo@uga.edu; marshgeo@gmail.com
}

Justine M. Ransdell

Division of Epidemiology

Department of Public Health Sciences

University of Miami | Miller School of Medicine

Cell: 207-350-5212

jmr477@miami.edu

Rory A. Walshe

Department of Geography

King's College London

Strand Campus

London WC2R 2LS, UK \&

Institute for Risk and Disaster Reduction,

University College London

+44 (0) 2078488720

rory.walshe@kcl.ac.uk

Ilan Kelman PhD

Reader in Risk, Resilience and Global Health

Institute for Risk and Disaster Reduction \& Institute

for Global Health

University College London

Gower Street London, WC1E 6BT, UK

+44 (0) 2031081338

i.kelman@ucl.ac.uk

University of Agder, Kristiansand, Norway

Sandro Galea, MD, DrPH

Dean

Robert A Knox Professor

School of Public Health

Boston University

715 Albany Street - Talbot 301

Boston, MA 02118

617-638-4644

sgalea@bu.edu

Hurricane Risks, Health Consequences, and Response Challenges

for Small Island Based Populations:

Observations from the 2017 Atlantic Hurricane Season 


\begin{abstract}
The intensely active 2017 Atlantic basin hurricane season provided an opportunity to examine how climate drivers, including warming oceans and rising seas, exacerbated tropical cyclone hazards. The season also highlighted the unique vulnerabilities of populations residing on small island developing states (SIDS) to the catastrophic potential of these storms. During 2017, 22 of the 29 Caribbean SIDS were affected by at least one named storm and multiple SIDS experienced extreme damage. This paper aims to review the multiplicity of storm impacts on Caribbean SIDS throughout the 2017 season, explicate the influences of climate drivers on storm formation and intensity, explore the propensity of SIDS to sustain severe damage and prolonged disruption of essential services, document the spectrum of public health consequences, and delineate the daunting hurdles that challenged emergency response and recovery operations for island-based, disaster-affected populations.
\end{abstract}

\author{
Abstract: 137 words \\ Narrative: 5,036 words \\ Key words: disaster, tropical cyclone, tropical storm, hurricane, climate change, \\ climate driver, hazard, vulnerability, risk, health consequences, disaster response, \\ Small Island Developing States
}




\section{Introduction}

The United Nations (UN) officially recognizes the precarious existence of 57 Small Island Developing States (SIDS), distributed across 3 vast ocean regions occupying the earth's tropical and sub-tropical beltline (Table 1). ${ }^{1-3}$ Twenty-nine of the SIDS are in the Caribbean Region. Throughout the highly-active 2017 Atlantic Basin hurricane season, a series of human population encounters with strong tropical cyclones underscored the vulnerabilities of SIDS to the impacts of climate-related storm hazards. The Caribbean SIDS sustained the brunt of human harm and public health consequences as well as structural damage and environmental devastation.

\section{INSERT TABLE 1 ABOUT HERE}

Aiming to advance our understanding of the particular burden faced by SIDS in the face of escalating vulnerabilities to hurricanes, we organized our discussion to 1 ) document the 2017 storm impacts on the Caribbean SIDS and then, in sequence, 2) describe the climate-related hazards that influenced the destructive capacity of the season's tropical cyclones, 3) outline the unique "disaster risk landscape" for SIDS, 4) summarize the cascades of hurricane health consequences, and 5) explore the constellation of challenges that impeded, and sometimes derailed, effective disaster response.

\section{Atlantic hurricane impacts on Caribbean Region SIDS}

Seventeen "named" tropical cyclones developed during the 2017 Atlantic Basin hurricane season, beginning in April and extending into early November, along with two weaker systems (a tropical depression and a potential tropical cyclone). ${ }^{4}$ Worldwide, tropical cyclones are variably termed hurricanes, typhoons, or cyclones depending upon their basin of origin. ${ }^{5}$ Atlantic storms are classified according to their peak sustained wind speeds and corresponding wind-focused damage estimates according to the Saffir-Simpson Hurricane Wind Scale (SSHWS). ${ }^{6}$ Tropical systems are named, using alphabetical lists, once they attain "tropical storm" force velocities (39-73 $\mathrm{mph}$ ). If wind speeds increase to $74 \mathrm{mph}$ or higher, the tropical storm graduates to 
"hurricane" status. Hurricanes are further classified, based on ranges of wind speeds, into Categories 1 through 5. The top 3 categories (3-5) are "major" hurricanes.

\section{INSERT FIGURE 1 ABOUT HERE}

Among the 17 named storms in 2017, 7 had their highest wind velocities in the tropical storm range while the other 10 storms attained hurricane wind speeds. Six hurricanes reached "major" hurricane status, with winds in excess of $110 \mathrm{mph}$.

We analyzed the National Hurricane Center (NHC) 2017 storm archive files, examining the map sequences to identify the SIDS that experienced tropical storm and/or hurricane wind fields during the passage of each storm. ${ }^{4}$ For each Atlantic basin named storm, the archive contains a series of maps, updated every 6 hours, displaying the path of the storm and the geographic center of circulation surrounded by a red oval denoting the area receiving hurricane force winds. The red oval was encircled, in turn, by a larger orange oval, showing the areal extent of tropical storm winds. For those frames displaying a system at tropical storm strength, but below hurricane strength, only an orange oval was visible on the map. We consulted the corresponding series of time-dated storm advisories to estimate the highest wind speeds for each storm's closest encounter with each of the impacted SIDS.

Table 2 provides an alphabetical enumeration of the $16 \mathrm{UN}$-member Caribbean SIDS (Table 2a) and the 13 non-UN-member Caribbean SIDS (Table $2 b$ ) in relation to the names and intensities of the 2017 storms that interacted with each of these island states. Twenty-two of the 29 SIDS (76\%) were affected by at least one storm and among these, 4 SIDS were affected by exactly 1 storm, 13 by two storms, and 5 by three storms (Box 1).

\section{INSERT TABLE 2 ABOUT HERE}

\section{INSERT BOX 1 ABOUT HERE}

Eleven SIDS experienced only tropical storm force winds from one or several storms and rebounded rapidly without major effect. In contrast, 11 SIDS were impacted by major hurricane force winds and 9 of these experienced a direct "landfall" as the eye of the storm came onshore and passed over the island. Major hurricane strikes were 
crippling for Puerto Rico, Dominica, and many of the island entities throughout the Leeward Islands. For example, Hurricane Irma rendered Barbuda uninhabitable. The eye of Hurricane Maria passed directly across Dominica, splintering the rainforests, destroying staple crops, and leaving houses roofless and in shambles. Puerto Rico and the US Virgin Islands were brought to standstill by island-wide power outages that continued for months. The combined economic costs for the 2017 storms are likely to exceed those of any previous year (although mainly as a result of damage to the US, rather than to SIDS), with Hurricane Harvey alone projected to be the costliest storm on record. 7,8

Table 3 provides a different perspective on the storm track data; here the 17 storms are listed alphabetically in relation to the SIDS that each storm affected. Nine of the 17 storms brought tropical storm or hurricane winds to at least one of the Caribbean SIDS. Seven of these 9 (Bret, Don, Franklin, Harvey, Jose, Nate, Philippe) brought only tropical storm force winds to SIDS although 4 of these storms (Franklin, Harvey, Jose, Nate) did attain hurricane strength along portions of their respective trajectories. For example, Harvey briefly brushed the Lesser Antilles as a tropical storm and then dissipated to a tropical wave as it moved westward and crossed Mexico's Yucatan Peninsula, but the bedraggled remnants of Harvey rejuvenated in the warm Gulf of Mexico, rapidly intensified to Category 4 strength, and deluged the US mainland, causing catastrophic precipitation and flooding in east Texas and Louisiana. ${ }^{9}$

Remarkably, just 2 major hurricanes, Irma and Maria, accounted for all of the 2017 hurricane force impacts on SIDS. Irma and Maria each pummeled a succession of SIDS at tropical storm or hurricane force over multiple days (Table 3, Figure 2, Figure 3). Irma affected a total of ${ }_{14}$ SIDS, including 5 at tropical storm force, one at Category 1 force, and 8 at major hurricane force. Maria impacted 16 SIDS, 11 at tropical storm force and 5 at major hurricane force. Three SIDS, the US Virgin Islands, Puerto Rico, and Turks and Caicos Islands, experienced hurricane velocity winds from both Irma and Maria. 
INSERT FIGURE 2 ABOUT HERE

INSERT FIGURE 3 ABOUT HERE

\section{Climate drivers and the 2017 Atlantic storms}

Strong hurricanes are statistically rare events, so the highly-active 2017 Atlantic season was notable for the number and collective intensity of the 17 named storms. $A$ key metric, "accumulated cyclone energy" (ACE), provides a summative measure of storm intensity for the entire basin. ACE was the highest on record for the month of September, $2017^{10}$ and seventh overall for the total hurricane season, based on data collected since $1851 .^{11}$

What was observed in 2017 represented a combination of natural climate variability and responses to ongoing "anthropogenic forcing" in the climate system (e.g., sea level rise and a long-term secular trend of increasing ocean temperatures). ${ }^{12}$ Add to this the lack of an El Niño signal, which tends to suppress Atlantic hurricane activity, and the synergism among these "climate drivers" contributed to a highlydestructive sequence of storms that wrought havoc on the Caribbean SIDS and US mainland. ${ }^{13-19}$ Moreover, the 2017 season may be considered a harbinger of the future, a telltale that the cyclone hazards faced by SIDS are likely to increase in severity (although possibly decrease in frequency) over the remainder of the $21^{\text {st }}$ century. ${ }^{13,14}$

Two highly salient climate drivers during the 2017 Atlantic hurricane season were anomalously warm ocean water and low vertical wind shear (VWS), which describes the way the winds change with height in the atmosphere. ${ }^{17}$ The ocean temperatures are instrumental in determining how strong a hurricane can become, while the VWS plays a key role in keeping hurricanes from achieving and/or maintaining their potential strength. ${ }^{17}$ The Caribbean SIDS are located in a region where anomalously warm water is naturally concurrent with low shear, creating a highly disadvantageous situation where the potential hurricane strength is high and there is only minimal shear-imposed constraint on reaching or maintaining this potential. 
Another salient climate driver during the 2017 Atlantic season was the anomalously great depth to which the warm ocean waters extended. Tropical cyclones are rotating heat engines that derive their immense power from the transfer of warmth from the ocean into the high atmosphere. When there is a deep layer of warm waters, the energy transfer is maintained even as the system churns the sea beneath its canopy of spiraling thunderstorms. 5

The preceding years, 2014 through 2016, had set 3 consecutive marks for the warmest year on record (based on data collected since 1850) and included one of the strongest observed El Niños, lasting from May 2014 through June 2016. ${ }^{15}$ The presence of El Niño potentiated vigorous tropical cyclone activity throughout the Pacific basins but concomitantly suppressed Atlantic storm development. ${ }^{15,17,20}$ The waning of El Niño during late 2016 prompted seasonal forecasters to make prescient predictions for an above-normal 2017 Atlantic basin hurricane season.

Climate drivers have interacted synergistically to make hurricanes stronger in recent years than they were even a few decades ago. ${ }^{16-18,21-23}$ Prominent hurricane hazards in 2017 were related to anomalously warm ocean temperatures, which coincides with low VWS in the Caribbean SIDS region. ${ }^{17,24-26}$

First, the storm season was prolonged, beginning with Tropical Storm Arlene in April, two months prior to the start of the official season. Second, the maximum peak wind speeds were elevated due to these high ocean temperatures (e.g. Hurricane Irma set an Atlantic basin record with sustained wind speeds in excess of $180 \mathrm{mph}$ for 36 consecutive hours). ${ }^{19}$ Third, most of the storms reached hurricane status; 10 storms in a row, Franklin through Ophelia, became hurricanes, including 6 major hurricanes. Fourth, rapid intensification prior to landfall characterized the strongest storms. ${ }^{17,20}$ Fifth, the atmospheric moisture-holding capacity was elevated due to high air temperatures, leading to increased precipitation rates and torrential rainfall totals (e.g. this phenomenon contributed to Hurricane Harvey setting a new US national total rainfall record, in tandem with the storm's excruciatingly slow track movement). ${ }^{9}$ Sixth, storm systems remained intact for extended durations which allowed them to approach 
and often reach their potential strength. Seventh, several major hurricanes significantly affected multiple SIDS and mainland human populations along the course of their trajectories (e.g. Irma interacted with 14 SIDS prior to traversing the entire Florida peninsula vertically, from the Florida Keys to the Panhandle). Eighth, storms coming across the Atlantic tracked along similar east-west pathways, leading to repeated strikes on the same human populations. Ninth, the 2017 season was consistent with analyses indicating that, "[tropical cyclones] will become stronger, larger, and unexpectedly more destructive under global warming. ${ }^{27}$

\section{High-vulnerability "disaster risk landscape" of SIDS}

Disaster risk is a function of the interaction of hazards and vulnerabilities. Cyclonic wind and water hazards, and their climate drivers, have been introduced. Now it is time to ask about the defining vulnerabilities of the SIDS that caused the extremity of harm inflicted by the 2017 storms and thwarted attempts to effectively mitigate and respond to these risks.

First, the Caribbean SIDS' tropical/sub-tropical coordinates place them in the ocean corridors where tropical systems form, roam, and strike. The birthing of most Atlantic tropical cyclones occurs within the "main development region" (MDR), a rectangular geographic area in the tropical Atlantic and Caribbean, extending from west Africa to eastern Mexico $\left(20^{\circ} \mathrm{W}\right.$ to $85^{\circ} \mathrm{W}$ longitude) between the latitudes of $10^{\circ}$ $\mathrm{N}$ and $20^{\circ} \mathrm{N} .{ }^{17}$ Within this hurricane-spawning swath of ocean real estate, most human settlement is situated on the islands, or clusters of islands, that comprise the Caribbean Region SIDS. ${ }^{1,2}$ Simply stated, SIDS residents inhabit the MDR.

As described by Kossin (2017), ${ }^{17}$ the MDR is the region where the dual effect of warm water and low shear primarily occurs. This is very different than the situation along the US east coast, where the shear sets up a natural hurricane gauntlet when the ocean in the SIDS region is warmer than normal. ${ }^{17}$ This is really a very unfortunate aspect of the Atlantic climate system for Caribbean SIDS residents (although it is advantageous for persons living along the US coastline). 
Second, as island states, the topography of SIDS features a $360^{\circ}$ sea-level coastal perimeter that is vulnerable to wave action and storm surge regardless of the direction of hurricane approach. ${ }^{1,2}$ Over time, rising sea levels are adding to the wave heights, storm surge volumes, and the coastal and inland areas susceptible to surge and inundation. Sea level rise also inhibits the ability of flooded inland areas to drain back into the ocean.

Third, many SIDS communities, especially those that populate coral atolls, have minimal elevation above sea level. During hurricanes, portions of these SIDS are prone to overtopping and prolonged submergence, rendering the storm-affected areas uninhabitable.

Fourth, other SIDS owe their formation and rugged verticality to volcanic activity (e.g. Dominica is a composite of 9 active volcanoes). The steep terrain is prone to mudslides and flash flooding as copious downpours pummel the island. Illustrating the "disaster risk landscape" in its most literal sense, as the moist air of the passing tropical system lifts upward over the mountains, it cools with altitude forming "orographic clouds" that enhance both the precipitation rate and the volume of rainfall within the hurricane's eyewall and rain bands.

Fifth, as islands, SIDS are physically remote and geographically disconnected from other land masses.1,2 Therefore, mitigating hazards and responding to cyclone impacts can be more logistically complex than for mainland locales. As a key distinction, mass population evacuation away from storm-threatened coastlines to safer inland locations is not feasible for the smallest SIDS and of limited utility even for larger islands; the size of the swirling cyclone completely dwarfs the dimensions of SIDS entities. ${ }^{19}$ Satellite images frequently display entire islands completely encircled by just the eye of the hurricane. As a further complication, once the storm has passed through, outside emergency response resources must be flown or ferried to the island, and as seen repeatedly in 2017, airports and docks may be severely damaged.

Sixth, many SIDS are not single islands but a conglomerate of many populated islands (e.g. The Bahamas is made up of more than 700 islands with dozens inhabited). 
The complexity of rescue and relief operations is increased by the need to disperse personnel and dispense materiel to pockets of survivors stranded on multiple islands.

Seventh, as the acronym implies, most SIDS are geographically small, relatively impoverished, comparatively non-industrialized ("developing"), and disproportionately challenged to achieve sustainable development. ${ }^{1,2}$ They have limited natural or manufactured resources (in contrast to several larger developed nations, such as Japan, that are also composed of islands). Understandably, SIDS economies generally cannot appropriate large expenditures for disaster preparedness. Moreover, as evidenced repeatedly in 2017 , formidable cyclones easily overwhelm the response capabilities of small islands.

Eighth, many SIDS face severe economic constraints related to finite resources, frail infrastructure, inadequate governance structures, and huge inequities in income and resource allocation. ${ }^{1,2}$ Centralized utilities and public services typically supply the entire island population; if disrupted by a storm, there are no back-up or replacement systems available on the island. During the 2017 storms, multiple Caribbean SIDS suffered catastrophic damage to their power grids, bringing the entire island to a halt.

Ninth, following decades of UN support and the recognition that, in order to achieve their Sustainable Development Goals, ${ }^{28}$ SIDS must develop partnerships among themselves and also with supportive developed nations as outlined in the Small Island Developing States Accelerated Modalities of Action (SAMOA) Pathway. ${ }^{2}$ However, prior to the 2017 Atlantic hurricane season - and while still acknowledging the work of CDEMA (Caribbean Disaster Emergency Management Agency), CCCCC (Caribbean Community Climate Change Centre), and each national disaster office - the Caribbean Region SIDS have not made major progress toward forging partnerships for mutual support when disasters strike. ${ }^{2}$ Therefore, when so many SIDS experienced calamitous storm encounters in 2017, the Caribbean region was rendered largely dependent upon outside aid.

\section{Cascading public health consequences}


The precise nature of human population exposures to hurricane hazards varied by locale, depending upon the storm's properties at that time and place, coupled with the local vulnerabilities of the peoples and the built environment. Residents of the SIDS territories affected by the 2017 storms faced a range of escalating health threats as they endured the impact phase, and then started rebuilding themselves while waiting for restoration of power, infrastructure, and health services after the storm passed.

Mortality. Tallies of storm-related deaths from tropical cyclones are typically modest in the modern post-satellite era because it is possible to detect large revolving atmospheric systems days in advance and warn the population to seek shelter during the impact phase. More deaths occur in the aftermath and most often from drowning. 5,29 With current storm detection technology, recent storm strikes on islandbased populations only rarely provide an exception to the generality regarding low mortality rates (one exception: there were 6,300 deaths during 2013 Super Typhoon Haiyan in the Philippines, with many deaths due to the massive storm surge)..$^{30}$ Providing a historical contrast, the "Great Hurricane" of 1780, the deadliest Atlantic hurricane in history, decimated the Lesser Antilles and Hispaniola, killing an estimated 22-27,000 persons. This storm was also the deadliest tropical cyclone worldwide to strike island-dwelling populations exclusively.

During 2017, the post-disaster conditions on the hardest-hit Caribbean SIDS led to progressively rising death tolls over a period of months as survivors faced prolonged power outages, shortages of basic necessities, and storm-debilitated health care systems. Puerto Rico provides a case-in-point. While the official death toll was 58 deaths 10 weeks after Hurricane Maria swept over the island on September 20, 2017, preliminary studies of "excess" deaths (compared to previous years) conducted by investigative journalists suggested that the death toll was about 20 times higher at that point and climbing. ${ }^{31}$ Carefully-designed epidemiologic analyses are needed to estimate the number and rate of preventable deaths and such studies are now underway in response to public clamor to depoliticize and objectively quantify Mariarelated excess mortality. ${ }^{32}$ 
A primary contributor to death was the unabated exposure of millions of survivors on the storm-affected SIDS to tropical heat and humidity. It is well known that, without taking preventive action, even moderate temperature elevations are associated with marginal increases in mortality 33 and this is an overlay to surges in deaths from sharp temperature spikes during heat waves. ${ }^{34-40} \mathrm{~A}$ variation of this occurred in Puerto Rico and the Leeward Islands where, in actuality, a protracted "heat wave" occurred by default; the long-duration power outages summarily "removed" the usual options for staying cool (air conditioning, electric fans). Indeed, vulnerability to heat-related mortality is greater in persons living without air conditioning, and excess cardiovascular and respiratory mortality has been documented in the elderly and persons with pre-existing chronic health conditions..$^{41-46}$

Morbidity: physical injury. The capability to warn populations to seek shelter as a tropical system approaches minimized the numbers of impact-phase injuries occurring as a result of trauma from projectile debris, broken glass, or crumbling structures. With tropical cyclones, the majority of injuries take place during clean-up and recovery and while navigating the damaged post-storm community environment. Injuries include falls, lacerations (notably chain-saw injuries), puncture wounds, abrasions, fractures, electrocutions, and motorized equipment injuries. 530,47-49

Morbidity: heat-related injury. The 2017 Atlantic season showcased the health effects of a warming planet; SIDS residents were exposed to heat-intensified storms that destroyed the power grids, and then, in the aftermath, to life-threatening Caribbean heat and humidity with heat indexes regularly over 37 degrees Celsius. ${ }^{24-26,50}$ This physiological stressor of inescapable heat exposure poses a severe and potentiallyfatal threat to health and well-being, most acutely experienced by persons with chronic diseases and the elderly..$^{38-40,50-54}$

Morbidity: decompensation of chronic disease symptoms. Most stormaffected SIDS experienced major disruptions of health services, related to flooded and damaged facilities, and aggravated by power outages and fuel shortages. The storms created extraordinary obstacles to the routine management of chronic diseases due to 
interrupted access to essential medications (e.g. for diabetes, hypertension, heart disease) and sites of care (physician offices, clinics, hospitals). Chronic health problems were further exacerbated by unrelieved heat exposure and inability to refrigerate medications. 55 Even with prioritization, it took SIDS populations weeks to reestablish such lifeline treatments as kidney dialysis and cancer therapies.

Morbidity: vector-borne diseases. Climate influences the distribution and density of vector populations and the Caribbean is endemic for such mosquito-borne infectious diseases as dengue, Zika, and chikungunya, raising concerns for the spread of known, and the emergence of new, infectious diseases.34,35,56-60.

Many SIDS citizens lost their roofs and windows during the 2017 storms allowing insect vectors unimpeded access to occupants who remained in these damaged structures. In addition to the withering heat, many survivors experienced days or weeks of displacement and living partially exposed to the elements without the possibility of protecting themselves from insect bites. While torrential rains washed away some insect eggs and larvae, storm debris allowed standing water to pool, providing optimal breeding conditions for mosquitoes; based on the post-impact experience following previous extreme weather events, the incidence rates for vector-transmitted diseases are anticipated to increase on the storm-impacted SIDS. ${ }^{61,62}$

Morbidity: diseases related to contaminated water. Disasters propel cascades of emerging infectious disease risks. $34,62,63$ On several SIDS, the storms triggered islandwide failure of the power grids which also disabled water treatment and sewage systems. This permitted cross-contamination of the water supply with wastewater containing human feces, urine, and seaborne bacteria. For example, a leptospirosis outbreak investigation was conducted in Puerto Rico several weeks after the passage of Hurricane Maria. Water contamination elevated risks for outbreaks of such diseases as dysentery, E. coli, and typhoid. In Puerto Rico, and very likely on other SIDS, water may have been contaminated with chemicals and pollutants from one of the island's 19 hazardous waste sites. 
Morbidity: mental health. Although yet to be documented for 2017, the most widespread and debilitating hurricane-related health effects for storm-impacted SIDS residents are likely to be the mental health sequelae. ${ }^{34,35,64-74}$ Without a viable option to evacuate, millions of SIDS residents were confined to their small islands, unable to avoid direct exposure to the strongest winds and storm surge from the center of the storm, preceded and followed by hours of flooding rainfall.

Psychological distress was almost universally experienced by SIDS residents who experienced tropical cyclone hazards. ${ }^{67-70}$ Direct and inescapable exposure to a potentially deadly threat is a strong risk factor for PTSD. $34,64-67,71,72$ For SIDS receiving major hurricane strikes, the extreme stressors and hardships faced in the aftermath predicted the likely onset of PTSD, depression or both. ${ }^{64-67,71-73}$ Progression to diagnosable psychopathology is likely to be prevalent for perhaps one-third of citizens who were close to the center of a life-threatening major hurricane..$^{71-73}$ Mental health risks are also elevated for such special populations as children, elderly, and persons with medical special needs including people with disabilities. ${ }^{34,64}$ For those with previouslydiagnosed severe and persistent mental disorders, disruption of routines, as well as barriers to accessing treatment and refilling psychiatric medications, may have led some psychiatric patients to decompensate.

Population displacement. The sequential hurricanes of 2017 precipitated population movements including the complete evacuation of Barbuda residents to Antigua; the partial evacuation of St. John and St. Thomas residents to St. Croix following Irma, only to take a direct strike weeks later from Maria; and the much more massive relocation of Puerto Rican residents to mainland US. ${ }^{76,77}$ Florida is receiving a continuous influx of American citizens from Puerto Rico who are resettling in the continental US with high likelihood of remaining "stateside."

\section{Daunting challenges for mounting effective disaster response}

The 2017 hurricane season posed challenges to multiple SIDS that received direct hits from Category 4/5 storms, impacts that far exceeded the local resources and 
summarily destroyed what response assets existed. Any buffering capacities to absorb the effects of powerful storms were outmatched and overwhelmed. Disaster response challenges for SIDS were complex and multi-layered.

First, it requires resources for SIDS to upgrade building codes, retrofit existing structures to withstand extreme wind speeds and towering surge, build durable highcapacity shelters, and maintain sizeable stockpiles of disaster supplies. Such resources were not made available over past decades, so the extant vulnerabilities were not redressed. Moreover, as ocean temperatures and sea levels rise, and storms become progressively stronger, the dangers for SIDS populations will increase, assuming the current built environment, and political priorities, remain static.

Second, the standard procedures of staging and prepositioning supplies and personnel nearby, and usually inland from, coastal hurricane impact zones prior to landfall is impractical for SIDS. It is not possible to know precisely which island entities will experience the center of the storm until just hours before impact. In 2017, this was the case for Dominica which was hit directly by the "pinpoint" eye of Category 5 Hurricane Maria, leaving the island nation in tatters. Meanwhile, Martinique, the next SIDS to the south, experienced only tropical storm force winds.

Third, severe damage to infrastructure, most notably the island power grid, sets off ripples of complications. All forms of civilian communications are hobbled, transportation is brought to standstill (due to debris-clogged and damaged roadways, fuel shortages, and inability to pump gasoline without power), schools and most forms of commerce are inoperable, and hospitals must resort to using generators to power a fraction of their most vital services. Emergency response activities can only self-sustain for a finite period before they must be replenished and recovery operations rely on restoration of basic infrastructure, particularly power.

Fourth, a damaging storm may simultaneously disable all levels of island government, including emergency management response capabilities. The incident management systems, designed to expand upward to accommodate the scale of a disaster cannot remain functional in a major incident that affects all levels. 
Fifth, outside assistance will not be timely because resources must be transported to SIDS by air or sea across an expanse of ocean; this requires time and operable airstrips and ports.

Sixth, for SIDS of even moderate size, plans and mechanisms must be available for transporting basic needs and essential supplies to all affected areas. The inability to deliver supplies to a high proportion of Puerto Rico's 78 municipalities was one of the most egregious shortcomings of the 2017 response to Hurricane Maria. Although the island territory measures only 100 miles in length by 35 miles in width, residents in the interior waited weeks or months for the establishment of a dependable supply line. The situation was exacerbated by fuel shortages and the debris-strewn condition of the roadways that were blocked by mudslides in some locales.

Seventh, during active storm seasons, a series of hurricanes may affect populations that are widely dispersed geographically, complicating the logistics of disaster response. The simultaneous and competing demands from many isolated subpopulations of survivors leads to a multi-front, diffuse set of simultaneous responses.

This was certainly the case for the US response to 3 strong 2017 storms: Hurricanes Harvey (Texas and Louisiana), Irma (US Virgin Islands, Florida), and Maria (US Virgin Islands, Puerto Rico). The differential attention and resource allocations provided by lead response agencies, including FEMA, to the storm-affected states and territories was notable. The response to Puerto Rico (a Caribbean SIDS that is a selfgoverning unincorporated territory of the US under FEMA's remit) following Hurricane Maria was grossly deficient in both timeliness and effectiveness, particularly when compared to the concurrent emergency operations dedicated to Hurricanes Harvey in Texas and Irma in Florida. In sharp contrast to the continental US emergency operations, the Puerto Rico response was accorded lower priority status, underpowered in terms of personnel, and inadequately funded and resourced.

Eighth, response is also hampered by the heterogeneity of SIDS governments. Many SIDS are independent sovereign states, some with historic affiliation to 
colonizing nations. Other SIDS have not sought or achieved statehood and currently are territories or protectorates of other countries. This creates variability, heterogeneity, duplication, and inefficiency of response efforts. The northern Leeward Island SIDS include the US Virgin Islands (St. John and St. Thomas were strongly affected by Hurricane Irma and St. Croix that was hit several weeks later by Hurricane Maria), the British Virgin Islands, and a single island that is co-habited by the French collectivity of Saint Martin in the north and by Sint Maarten, Kingdom of the Netherlands, in the south. Nearby is Anguilla, a British Overseas Territory, and the independent Commonwealth of Antigua and Barbuda, a sovereign state. Although these SIDS are in close geographic proximity, and all were severely impacted by Irma, Maria, or both, the disaster response involved a diversity of international partners.

Ninth, these barriers to mounting an effective response interrelate in complex and compounding ways. What is clear is that the multi-front preparedness and response to the impacts of a succession of powerful hurricanes, involving a variety of partners from a range of nations, trying to cover multiple jurisdictions simultaneously, has not gone well. None of the SIDS that sustained direct landfalls from a major hurricane (primarily Irma and Maria) successfully regained functionality several months after the storms.

Tenth, perhaps most generalizable and pronounced, the realization that was brought home strongly during the 2017 Atlantic hurricane season is that the SIDS are "experiencing a crisis created by environmental injustice. ${ }^{41,78,79}$ The contribution of the Caribbean SIDS to climate change is infinitesimally small, yet the climate-driven hazards faced by these island entities is outsized and disproportionate, not helped by internal and external drivers of vulnerabilities which ultimately caused the witnessed hurricane disasters.

\section{Concluding comments}

In the composite, the 2017 Atlantic hurricanes elucidated the changing disaster risk landscape for human population encounters with weather-related hazards, 
potentiated by significant climate and vulnerability influences. The 2017 hurricane season demonstrated that disaster risks are not equitably distributed but are much greater for populations with greater vulnerabilities, illustrated by the disproportionate storm consequences sustained by the inhabitants of Caribbean Region SIDS.

Climatological hazards are projected to change rapidly over the remainder of the $21^{\text {st }}$ century as are vulnerabilities to these hazards. Specifically, tropical cyclone risks - exposures of vulnerable human populations to hurricane hazards - are likely to increase due to lack of adequate action on climate change and on vulnerabilities. As an ironic testament to environmental injustice and to inequity, the populations occupying the SIDS contribute very minimally to the processes that are accelerating the warming of oceans, the rising of seas, the rate and volume of tropical precipitation, and the intensification of cyclones, yet these very populations bear the highest risks for harm, especially because vulnerabilities are not being properly addressed. 


\section{References}

1. United Nations. Small island developing states: small islands big(ger) stakes. Office of the High Representative for the Least Developed Countries, Landlocked Developing Countries and Small Island Developing States, United Nations, New York, NY. http://unohrlls.org/customcontent/uploads/2013/08/SIDS-Small-Islands-Bigger-Stakes.pdf. Published 2011. Accessed December 28, 2017.

2. United Nations Department of Economic and Social Affairs, Steering Committee on SIDS Partnerships. Partnerships on Small Island Developing States 2016.

3. United Nations. Sustainable Development Knowledge Platform: Small Island Developing States. https://sustainabledevelopment.un.org/topics/sids/list. Accessed December 28, 2017.

4. National Hurricane Center. 2017 Tropical Cyclone Advisory Archive. http://www.nhc.noaa.gov/archive/2017/ . Accessed December 28, 2017.

5. Shultz JM, Russell JA Espinel Z. Epidemiology of tropical cyclones: the dynamics of disaster, disease, and development. Epidemiol Rev. 2005; 27(1):2135 .

6. National Hurricane Center. Saffir-Simpson Hurricane Wind Scale. http://www.nhc.noaa.gov/aboutsshws.php. Accessed December 28, 2017.

7. Accuweather.com. Harvey, Irma damages predicted to cost $\$ 290$ billion; Atlantic hurricane season only at midpoint.

https://www.accuweather.com/en/weather-news/harvey-irma-damagespredicted-to-cost-2go-billion-atlantic-hurricane-season-only-atmidpoint/70002711. Published September 12, 2017. Accessed December 28, 2017.

8. Drye W. 2017 Hurricane Season Was the Most Expensive in U.S. History. National Geographic, November 30, 2017. https://news.nationalgeographic.com/2017/11/2017-hurricane-season-mostexpensive-us-history-spd/. Published November 30, 2017. Accessed December 28, 2017.

9. Shultz JM, Galea S. Mitigating the mental and physical health consequences of Hurricane Harvey [published online October 17, 2017]. JAMA. 2017; 318(15):1437-1438. http://dx.doi.org/10.1001/jama.2017.14618. 
10. Capucci M. September is the most energetic month for hurricanes ever recorded in the Atlantic. https://www.washingtonpost.com/news/capitalweather-gang/wp/2017/og/26/september-is-the-most-energetic-month-forhurricanes-ever-recorded-in-the-atlantic/?utm_term=.14dc2d9557ea. Published September 27, 2017. Accessed December 28, 2017.

11. Klotzbach PJ, Bell MM. Summary of the 2017 Atlantic tropical cyclone activity and verification of the authors' seasonal and two-week forecasts. Colorado State University. November 30, 2017.

https://tropical.colostate.edu/media/sites/111/2017/11/2017-11.pdf

Published November 30, 2017. Accessed December 28, 2017.

12. Myhre G, Shindell $D$, Bréon F-M, et al. Anthropogenic and Natural Radiative Forcing. In: Stocker TF, Qin D, Plattner G-K, Tignor M, Allen SK, Boschung J, Nauels A, Xia Y, Bex V, Midgley PM eds. Climate Change 2013: The Physical Science Basis. Contribution of Working Group I to the Fifth Assessment Report of the Intergovernmental Panel on Climate Change. Cambridge, United Kingdom and New York, NY, USA.: Cambridge University Press; 2013:659-728.

13. Walsh KJE, McBride JL, Klotzbach PJ, et al. Tropical cyclones and climate change [published online November 11, 2015]. WIREs Clim Change. 2016; 7:6589. http://dx.doi.org/10.1002/wcc.371.

14. Knutson TR, McBride JL, Chan J, et al. Tropical cyclones and climate change [published online February 21, 2010]. Nat Geosci. 2010; 3:157-63. http://dx.doi.org/10.1038/ngeo77g.

15. Shultz JM, Shepherd JM, Bagrodia R, et al. Disaster Health Briefing: Tropical cyclones in a year of rising global temperatures and a strengthening El Niño. Disaster Health. 2015; 2(3-4):151-162.

16. Emanuel KA. The hurricane-climate connection. Bull Amer Meteor Soc. 2008; 89: ES10-ES20.

17. Kossin JP. Hurricane intensification along United States coast suppressed during active hurricane periods [published online January 4, 2017]. Nature. 2017; 549:390-393. http://dx.doi.org/10.1038/nature20783.

18. Kossin JP, Olander TL, Knapp KR. Trend analysis with a new global record of tropical cyclone intensity. J Clim. 2013; 26 9960-9976

19. Shultz JM, Galea S. Preparing for the next Harvey, Irma, or Maria - addressing research gaps [published online November 9, 2017]. N Engl J Med. 2017; 
377(19):1804-1806. http://dx.doi.org/10.1056/NEJMp1712854.

20. Jin FF, Boucharel J, Lin II. Eastern Pacific tropical cyclones intensified by El Niño delivery of subsurface ocean heat [published online December 3, 2014]. Nature. 2014; 516(7529):82-85. http://dx.doi.org/10.1038/nature13958.

21. Emanuel KA. Increasing destructiveness of tropical cyclones over the past 30 years. Nature. 2005; 436: 686-688.

22. Mann ME, Emanuel KA. Atlantic hurricane trends linked to climate change. EOS. 2006; 87:233-44.

23. Reed AJ, Mann ME, Emanuel KA, et al. Increased threat of tropical cyclones and coastal flooding to New York City during the anthropogenic era. Proc Nat Acad Sci. 2015; 112: 12610-5.

24. Coumou D, Robinson A, Rahmstorf S. Global increase in record-breaking monthly-mean temperatures [published online January 12, 2013]. Clim Change. 2013; 118:771-782. http://dx.doi.org/10.1007/s10584-012-0668-1.

25. Cai W, Borlace $S$, Lengaigne $M$, et al. Increasing frequency of extreme El Niño events due to greenhouse warming [published online January 19, 2014]. Nat Clim Change. 2014; 4:111-116. http://dx.doi.org/10.1038/nclimate2100.

26. Rahmstorf $S$, Coumou D. Increase of extreme events in a warming world [published online October 24, 2011]. PNAS. 2011; 108: 17905-17909; PMID:22025683. http://dx.doi.org/10.1073/pnas.1101766108.

27. Sun Y, Zhong Z, Li T, et al. Impact of ocean warming on tropical cyclone size and Its destructiveness [published online August 15, 2017]. Sci Rep. 2017; 7:8154. http://dx.doi.org/10.1038/s41598-017-08533-6.

28. United Nations. Sustainable Development Goals: 17 goals to transform our world. http://www.un.org/sustainabledevelopment/sustainable-developmentgoals/. Accessed December 28, 2017.

29. Seil K, Spira-Cohen A, Marcum J. Injury deaths related to Hurricane Sandy, New York City, 2012 [published online April 13, 2016]. Disaster Med Public Health Prep. 2016; 10(3):378-385. http://dx.doi.org/10.1017/dmp.2016.36.

30. Ching PK, Carr de los Reyes V, Sucaldito MN, et al. An assessment of disasterrelated mortality post-Haiyan in Tacloban City [published online November 6, 
2015]. Western Pac Surveill Response J. 2015; 6 Suppl 1:34-38.

http://dx.doi.org/10.5365/wpsar.2015.6.2.HYN 005.

31. Robles F, Davis K, Fink S, Almukhtar S. Official Toll in Puerto Rico: 64.

Actual Deaths May Be 1,052. New York Times.

https://www.nytimes.com/interactive/2017/12/08/us/puerto-rico-hurricanemaria-death-toll.html. Published December 9, 2017. Accessed December 28, 2017.

32. Mazzei P. Puerto Rico Orders Review and Recount of Hurricane Deaths. New York Times. December 18, 2017.

https://www.nytimes.com/2017/12/18/us/puerto-rico-hurricane-maria-deathtoll-review.html. Published December 18, 2017. Accessed December 28, 2017.

33. Wellenius GA, Eliot MN, Bush KF, et al. Heat-related morbidity and mortality in New England: Evidence for local policy [published online May 9, 2017]. Environ Res. 2017; 156:845-853. http://dx.doi.org/10.1016/j.envres.2017.02.005.

34. Patz JA, Frumkin $\mathrm{H}$, Holloway $\mathrm{T}$, et al. Climate change Challenges and opportunities for global health [published online September 22, 2014]. JAMA. 2014; 312(15):1565-1580.

http://dx.doi.org/10.1001/jama.2014.13186.

35. Patz JA, Grabow ML, Limaye VS. When it rains, it pours: Future climate extremes and health [published online November 25, 2014]. Ann Glob Health. 2014; 80:332-344. http://dx.doi.org/10.1016/j.aogh.2014.09.007.

36. Bobb JF, Peng RD, Bell ML, et al. Heat-related mortality and adaptation to heat in the United States [published online April 29, 2014]. Environ Health Perspect. 122(8):811-816. http://dx.doi.org/10.128g/ehp.1307392.

37. Peng RD, Bobb JF, Tebaldi $C$, et al. Toward a quantitative estimate of future heat wave mortality under global climate change [published online December 30, 2010]. Environ Health Perspect. 2011; 119(5):701-706.

http://dx.doi.org/10.1289/ehp.1002430.

38. Anderson BG, Bell ML. Weather-related mortality: How heat, cold, and heat waves affect mortality in the United States [published online June 4, 2009]. Epidemiology. 2009; 20(2): 205-213. http://dx.doi.org/10.1097/EDE.obo13e31819oeeo8.

39. Lee JY, Kim H. Projection of future temperature-related mortality due to climate and demographic changes. [published online June 15, 2016]. Environ 
Int. 2016. 94:489-494. http://dx.doi.org/10.1016/j.envint.2016.06.007.

40. Nordio F, Zanobetti A, Colicino E, et al. Changing patterns of the temperaturemortality association by time and location in the US, and implications for climate change. Environ Int. 2015. 81:80-86.

41. Levy BS, Patz JA. Climate Change, Human Rights, and Social Justice [published online August 14, 2015]. Ann Glob Health. 2015; 81(3):310-322. http://dx.doi.org/10.1016/j.aogh.2015.08.008.

42. Keller RC. Social dimensions of heat waves. In: Levy BS, Patz JA eds. Climate Change and Public Health. New York: Oxford University Press; 2015:97e8.

43. Boeckmann $\mathrm{M}$, Zeeb $\mathrm{H}$. Justice and equity implications of climate change adaptation: A theoretical evaluation framework [published online September 7, 2016]. Healthcare. 2016; 465. http://dx.doi.org/10.3390/healthcare 4030065.

44. Harlan SL, Brazel AJ, Prashad L, et al. Neighborhood microclimates and vulnerability to heat stress. Soc Sci Med. 2006; 63: 2847-2863.

45. Schaffer A, Muscatello D, Broome R, et al. Emergency department visits, ambulance calls, and mortality associated with an exceptional heat wave in Sydney, Australia, 2011: A time-series analysis [published online January 24, 2012]. Environ Health. 2012; 11(1):3. http://dx.doi.org/10.1186/1476-06gX-11-3.

46. Huang $C$, Barnett $A G$, Wang $X$, et al. Effects of extreme temperatures on years of life lost for cardiovascular deaths: A time series study in Brisbane, Australia. Circ Cardiovasc Qual Outcomes. 2012; 5:609-614.

47. Kim YW, Kim SY, Kim H, et al. Disaster-related injury management: High prevalence of wound infection after Super Typhoon Haiyan [published online September 2, 2015]. Disaster Med Public Health Prep. 2016; 10(1):28-33. http://dx.doi.org/10.1017/dmp.2015.100.

48. Garbern SC, Ebbeling LG, Bartels SA. A systematic review of health outcomes among disaster and humanitarian responders [published online September 19, 2016]. Prehosp Disaster Med. 2016; 31(6):635-642. http://dx.doi.org/10.1017/S1049023X16000832.

49. Brackbill RM, Caramanica $K$, Maliniak $M$, et al. Nonfatal injuries 1 Week after Hurricane Sandy - New York City Metropolitan Area, October 2012. MMWR. 2014; 63(42):950-954.

50. Forzieri G, Cescatti A, Batista e Silva F, et al. Increasing risk over time of 
weather-related hazards to the European population: a data-driven prognostic study. Lancet Planet Health. 2017; 1: e200-08

51. Lin S, Luo M, Walker RJ, et al. Extreme High Temperatures and Hospital Admissions for Respiratory and Cardiovascular Diseases [published online September 1, 2009]. Epidemiology. 2009; 20:738. http://dx.doi.org/10.1097/EDE.obo13e3181ad5522.

52. Petkova EP, Bader DA, Anderson GB, et al. Heat-Related Mortality in a Warming Climate: Projections for 12 U.S. Cities [published online October 31, 2014]. Int J Environ Res Public Health. 2014; 11:11371-11383.

http://dx.doi.org/10.3390/ijerph111111371.

53. Mathes RW, Ito K, Lane K, et al. Real-time surveillance of heat-related morbidity: Relation to excess mortality associated with extreme heat [published online September 6, 2017]. PLOS ONE. 2017; 12(9): e0184364. http://dx.doi.org/10.1371/journal.pone.0184364.

54. Anderson GB, Bell ML. Heat waves in the United States: Mortality risk during heat waves and effect modification by heat wave characteristics in 43 U.S. communities [published online October 7, 2010]. Environ Health Perspect. 2011; 119:210-218. http://dx.doi.org/10.128g/ehp.1002313.

55. Benigno MR, Kleinitz $P$, Calina $L$, et al. Responding to the health and rehabilitation needs of people with disabilities post-Haiyan [published online November 6, 2015]. Western Pac Surveill Response J. 2015; 6 Suppl 1:53-59. http://dx.doi.org/10.5365/wpsar.2015.6.2.HYN 010.

56. Patz JA, Epstein PR, Burke TA, et al. Global climate change and emerging infectious diseases. JAMA. 1996; 275(3):217-223.

57. Patz JA, Hahn MB. Climate change and human health: a one health approach. In: Mackenzie JS, Jeggo M, Daszak P, Richt JA eds. One Health: The HumanAnimal-Environment Interfaces in Emerging Infectious Diseases. New York, NY: Springer; 2013: 141-171.

58. Kovats R, Campbell-Lendrum D, McMichel A, et al. Early effects of climate change: do they include changes in vector-borne disease? Philos Trans $R$ Soc Lond B Biol Sci. 2001; 356: 1057-1068.

59. Mills JN, Gage KL, Khan AS. Potential influence of climate change on vector-borne and zoonotic diseases: a review and proposed research plan. Environ Health Perspect. 2010; 118:1507-1514. 
6o. Reiter P. Climate change and mosquito-borne disease. Environ Health Perspect. 2001; 109(suppl 1):141-161.

61. Aumentado C, Cerro BR, Olobia L, et al. The prevention and control of dengue after Typhoon Haiyan [published online November 6, 2015]. Western Pac Surveill Response J. 2015; 6 Suppl 1:60-65. http://dx.doi.org/10.5365/wpsar.2015.6.3.HYN 018.

62. McMichael AJ. Extreme weather events and infectious disease outbreaks. Virulence. $2015 ; 6(6): 543-547$.

63. Altizer S, Ostfeld RS, Johnson PT, et al. Climate change and infectious diseases: from evidence to a predictive framework. Science. 2013; 341(6145):514-519.

64. Goldman E, Galea S. Mental health consequences of disasters. Annu Rev Public Health. 2014; 35:169-183.

65. Neria Y, Shultz JM. Mental health effects of Hurricane Sandy: characteristics, potential aftermath, and response [published online December 26, 2012]. JAMA. 2012; 308(24):2571-2572. http://dx.doi.org/10.1001/jama.2012.110700.

66. Ruggiero KJ, Gros K, McCauley JL, et al. Mental health outcomes among adults in Galveston and Chambers counties after Hurricane Ike. Disaster Med Public Health Prep. 2012; 6(1):26-32. http://dx.doi.org/10.1001/dmp.2012.7.

67. Shultz JM, Cela T, Marcelin LH, et al. The trauma signature of 2016 Hurricane Matthew and the psychosocial impact on Haiti [published online November 28, 2016]. Disaster Health. 2016; 3(4):121-138.

http://dx.doi.org/10.1080/21665044.2016.1263538.

68. Schwartz R, Liu B, Sison C, et al. Study design and results of a populationbased study on perceived stress following Hurricane Sandy [published online December 2, 2015]. Disaster Med Public Health Prep. 2016; 10(3):325-332. http://dx.doi.org/10.1017/dmp.2015.157.

69. Galea S, Brewin CR, Gruber M, et al. Exposure to hurricane-related stressors and mental illness after Hurricane Katrina [published online June 27, 2007]. Arch Gen Psychiatry 2007; 64:1427-1434. http://dx.doi.org/10.1001/archpsyc.64.12.1427.

70. Lowe SR, Tracy M, Cerdá $M$, et al. Immediate and longer-term stressors and the mental health of Hurricane Ike survivors. J Trauma Stress. 2013; 26(6):753761. http://dx.doi.org/10.1002/jts.21872. 
71. Galea S, Nandi A, Vlahov D. The epidemiology of post-traumatic stress disorder after disasters [published online July 1, 2005]. Epidemiol Rev 2005; 27(1):78-91. http://dx.doi.org/10.1093/epirev/mxioo3.

72. Neria $Y$, Nandi A, Galea S. Posttraumatic stress disorder following disasters: a systematic review. Psychol Med 2008; 38(4):467-480.

73. Tracy M, Norris, FH, Galea S. Differences in the determinants of posttraumatic stress disorder and depression after a mass traumatic event [published online May 26, 2011]. Depress Anxiety. 2011; 28(8):666-675. http://dx.doi.org/10.1002/da.20838.

74. Galea S, Tracy M, Norris F, et al. Financial and social circumstances and the incidence and course of PTSD in Mississippi during the first two years after Hurricane Katrina. J Trauma Stress. 2008; 21:357-68.

http://dx.doi.org/10.1002/jts.20355.

75. Rechkemmer A, O'Connor A, Rai A, et al. A complex social-ecological disaster: Environmentally-induced forced migration [published online December 18, 2016]. Disaster Health. 2016; 3(4):112120.http://dx.doi.org/10.1080/21665044.2016.1263519

76. Shepherd M. Are hurricanes creating climate refugees in the Caribbean? Forbes.

https://www.forbes.com/sites/marshallshepherd/2017/og/21/are-hurricanescreating-climate-refugees-in-the-caribbean/\#18eob5ce5eg7

Published September 21, 2017. Accessed December 28, 2017.

77. Alvarez L. A great migration from Puerto Rico is set to transform Orlando. New York Times.

https://www.nytimes.com/2017/11/17/us/puerto-ricans-orlando.html? r=0 Published November 17, 2017. Accessed December 28, 2017.

78. McKenna P. What's happening in Puerto Rico is environmental injustice. Climate experts have long warned of the increasing risks of such a catastrophe. Inside Climate News/Republished by Slate.com.

Published September 27, 2017.

Accessed December 28, 2017. 
79. Patz JA, Gibbs HK, Foley JA, et al. Climate change and global health: Quantifying a growing ethical crisis [published online November 30, 2007]. EcoHealth. 2007; 4:397-405. http://dx.doi.org/10.1007/s10393-007-0141-1.

Link for reference 78 (does not format correctly): http://www.slate.com/articles/health_and_science/science/2017/0g/puerto_rico_is _experiencing_a_crisis_created_by_environmental_injustice.html 


\section{Box 1}

- 9-of-17 named storms brought tropical storm or hurricane force winds to one or more Caribbean Region SIDS

- 22-of-29 Caribbean SIDS were each impacted by 1-to-3 named storms

- 4 SIDS were affected by 1 storm, 13 by two storms, 5 by three storms

- For 11 Caribbean SIDS, maximal winds speeds were tropical storm force

- For 11 Caribbean SIDS, maximal wind speeds were major hurricane force

- 9-of-29 Caribbean SIDS experienced direct "landfall" of a major hurricane 


\section{Table 1: 57 Small Island Developing States (SIDS) by region}

Caribbean Region (29)
Coordinating entity: Caribbean Community

\begin{tabular}{|c|c|c|}
\hline \multicolumn{2}{|l|}{ United Nations members (16) } & Non-UN-members (13) \\
\hline $\begin{array}{l}\text { Antigua and Barbuda } \\
\text { Bahamas } \\
\text { Barbados } \\
\text { Belize } \\
\text { Cuba } \\
\text { Dominica } \\
\text { Dominican Republic } \\
\text { Grenada }\end{array}$ & $\begin{array}{l}\text { Guyana } \\
\text { Haiti } \\
\text { Jamaica } \\
\text { Saint Kitts and Nevis } \\
\text { Saint Lucia } \\
\text { Saint Vincent and the } \\
\text { Grenadines } \\
\text { Suriname } \\
\text { Trinidad and Tobago }\end{array}$ & $\begin{array}{l}\text { Anguilla } \\
\text { Aruba } \\
\text { Bermuda } \\
\text { British Virgin Islands } \\
\text { Cayman Islands } \\
\text { Curacao } \\
\text { Guadeloupe } \\
\text { Martinique } \\
\text { Montserrat } \\
\text { Puerto Rico } \\
\text { Sint Maarten } \\
\text { Turks and Caicos Islands } \\
\text { United States Virgin Islands }\end{array}$ \\
\hline \multicolumn{3}{|c|}{$\begin{array}{l}\text { Pacific Region (20) } \\
\text { Coordinating entity: Pacific Islands Forum }\end{array}$} \\
\hline \multicolumn{2}{|l|}{ United Nations members (13) } & Non-UN-members (7) \\
\hline $\begin{array}{l}\text { Federated States of Micronesia } \\
\text { Fiji } \\
\text { Kiribati } \\
\text { Marshall Islands } \\
\text { Nauru } \\
\text { Palau } \\
\text { Papua New Guinea }\end{array}$ & $\begin{array}{l}\text { Samoa } \\
\text { Solomon Islands } \\
\text { Timor-Leste } \\
\text { Tonga } \\
\text { Tuvalu } \\
\text { Vanuatu }\end{array}$ & $\begin{array}{l}\text { American Samoa } \\
\text { Commonwealth of } \\
\text { Northern Marianas } \\
\text { Cook Islands } \\
\text { French Polynesia } \\
\text { Guam } \\
\text { New Caledonia } \\
\text { Nive }\end{array}$ \\
\hline \multicolumn{3}{|c|}{$\begin{array}{l}\text { Africa Indian Ocean Mediterranean and South China Sea (AIMS) Region (8) } \\
\text { Coordinating entity: Indian Ocean Commission }\end{array}$} \\
\hline United Nations members (8) & & Non-UN-members (o) \\
\hline $\begin{array}{l}\text { Cabo Verde } \\
\text { Comoros } \\
\text { Guinea-Bissau } \\
\text { Maldives }\end{array}$ & $\begin{array}{l}\text { Mauritius } \\
\text { Sao Tomé and Principe } \\
\text { Seychelles } \\
\text { Singapore }\end{array}$ & \\
\hline
\end{tabular}

\section{Table $2 a$}

Small Island Developing States (SIDS) in the Caribbean Region: UN Members 2017 Atlantic hurricane basin tropical cyclone impacts and category at closest approach/landfall 


\begin{tabular}{|c|c|c|c|}
\hline $\begin{array}{l}\text { Small Island Developing States } \\
\text { (SIDS): } 16 \text { Caribbean } \\
\text { Region UN Members }\end{array}$ & Tropical Cyclone & $\begin{array}{l}\text { Highest classification } \\
\text { category experienced for } \\
\text { each of the affected SIDS }\end{array}$ & $\begin{array}{l}\text { Hurricane } \\
\text { landfall }\end{array}$ \\
\hline Antigua and Barbuda & $\begin{array}{l}\text { Irma } \\
\text { Jose } \\
\text { Maria }\end{array}$ & $\begin{array}{l}\text { Category } 5 \text { Hurricane } \\
\text { Tropical Storm } \\
\text { Tropical Storm }\end{array}$ & Yes \\
\hline Bahamas & $\begin{array}{l}\text { Irma } \\
\text { Maria } \\
\text { Philippe }\end{array}$ & $\begin{array}{l}\text { Tropical Storm } \\
\text { Tropical Storm } \\
\text { Tropical Storm }\end{array}$ & \\
\hline Barbados & $\begin{array}{l}\text { Harvey } \\
\text { Maria }\end{array}$ & $\begin{array}{l}\text { Tropical Storm } \\
\text { Tropical Storm }\end{array}$ & \\
\hline Belize & Franklin & Tropical Storm & \\
\hline Cuba & $\begin{array}{l}\text { Irma } \\
\text { Nate } \\
\text { Philippe }\end{array}$ & $\begin{array}{l}\text { Category } 4 / 5 \text { Hurricane } \\
\text { Tropical Storm } \\
\text { Tropical Storm }\end{array}$ & Yes \\
\hline Dominica & Maria & Category 5 Hurricane & Yes \\
\hline Dominican Republic & $\begin{array}{l}\text { Irma } \\
\text { Maria }\end{array}$ & $\begin{array}{l}\text { Tropical Storm } \\
\text { Tropical Storm }\end{array}$ & \\
\hline Grenada & $\begin{array}{l}\text { T.S. Bret } \\
\text { T.S. Don }\end{array}$ & $\begin{array}{l}\text { Tropical Storm } \\
\text { Tropical Storm }\end{array}$ & \\
\hline Guyana & \multicolumn{3}{|c|}{ No impacts from 2017 Atlantic tropical cyclones } \\
\hline Haiti & Irma & Tropical Storm & \\
\hline Jamaica & \multicolumn{3}{|c|}{ No impacts from 2017 Atlantic tropical cyclones } \\
\hline Saint Kitts and Nevis & $\begin{array}{l}\text { Irma } \\
\text { Maria }\end{array}$ & $\begin{array}{l}\text { Category } 5 \text { Hurricane } \\
\text { Tropical Storm }\end{array}$ & No \\
\hline Saint Lucia & $\begin{array}{l}\text { Harvey } \\
\text { Maria }\end{array}$ & $\begin{array}{l}\text { Tropical Storm } \\
\text { Tropical Storm }\end{array}$ & \\
\hline $\begin{array}{l}\text { Saint Vincent and the } \\
\text { Grenadines }\end{array}$ & $\begin{array}{l}\text { T.S. Don } \\
\text { Harvey }\end{array}$ & $\begin{array}{l}\text { Tropical Storm } \\
\text { Tropical Storm }\end{array}$ & \\
\hline Suriname & \multicolumn{3}{|c|}{ No impacts from 2017 Atlantic tropical cyclones } \\
\hline Trinidad and Tobago & $\begin{array}{l}\text { T.S. Bret } \\
\text { T.S. Don }\end{array}$ & $\begin{array}{l}\text { Tropical Storm } \\
\text { Tropical Storm }\end{array}$ & \\
\hline
\end{tabular}




\begin{tabular}{|c|c|c|c|}
\hline \multicolumn{4}{|c|}{$\begin{array}{l}\text { Table } 2 b \\
\text { Small Island Developing States (SIDS) in the Caribbean Region: Non-UN Members } \\
2017 \text { Atlantic hurricane basin tropical cyclone impacts and category at closest approach/landfall }\end{array}$} \\
\hline $\begin{array}{l}\text { Small Island Developing States } \\
\text { (SIDS): } 13 \text { Caribbean Region } \\
\text { Non-UN IMembers }\end{array}$ & Tropical Cyclone & $\begin{array}{l}\text { Highest classification } \\
\text { category experienced for } \\
\text { each of the affected SIDS }\end{array}$ & $\begin{array}{l}\text { Hurricane } \\
\text { landfall? }\end{array}$ \\
\hline Anguilla & $\begin{array}{l}\text { Irma } \\
\text { Jose } \\
\text { Maria }\end{array}$ & $\begin{array}{l}\text { Category } 5 \text { Hurricane } \\
\text { Tropical Storm } \\
\text { Tropical Storm }\end{array}$ & Yes \\
\hline Aruba & \multicolumn{3}{|c|}{ No impacts from 2017 Atlantic tropical cyclones } \\
\hline Bermuda & \multicolumn{3}{|c|}{ No impacts from 2017 Atlantic tropical cyclones } \\
\hline British Virgin Islands & $\begin{array}{l}\text { Irma } \\
\text { Maria }\end{array}$ & $\begin{array}{l}\text { Category } 5 \text { Hurricane } \\
\text { Tropical Storm }\end{array}$ & Yes \\
\hline Cayman Islands & \multicolumn{3}{|c|}{ No impacts from 2017 Atlantic tropical cyclones } \\
\hline Curacao & \multicolumn{3}{|c|}{ No impacts from 2017 Atlantic tropical cyclones } \\
\hline Guadeloupe & $\begin{array}{l}\text { Irma } \\
\text { Maria }\end{array}$ & $\begin{array}{l}\text { Tropical Storm } \\
\text { Category } 5 \text { Hurricane }\end{array}$ & No \\
\hline Martinique & Maria & Tropical Storm & \\
\hline Montserrat & $\begin{array}{l}\text { Irma } \\
\text { Maria }\end{array}$ & $\begin{array}{l}\text { Tropical Storm } \\
\text { Tropical Storm }\end{array}$ & \\
\hline Puerto Rico & $\begin{array}{l}\text { Irma } \\
\text { Maria }\end{array}$ & $\begin{array}{l}\text { Tropical Storm/ } \\
\text { Category } 1 \text { Hurricane } \\
\text { Category } 4 / 5 \text { Hurricane }\end{array}$ & $\begin{array}{l}\text { No } \\
\text { Yes }\end{array}$ \\
\hline Sint Maarten & $\begin{array}{l}\text { Irma } \\
\text { Jose } \\
\text { Maria }\end{array}$ & $\begin{array}{l}\text { Category } 5 \text { Hurricane } \\
\text { Tropical Storm } \\
\text { Tropical Storm }\end{array}$ & Yes \\
\hline Turks and Caicos Islands & $\begin{array}{l}\text { Irma } \\
\text { Maria }\end{array}$ & $\begin{array}{l}\text { Category } 5 \text { Hurricane } \\
\text { Category } 3 \text { Hurricane }\end{array}$ & $\begin{array}{l}\text { Yes } \\
\text { No }\end{array}$ \\
\hline U.S. Virgin Islands & $\begin{array}{l}\text { Irma } \\
\text { Maria }\end{array}$ & $\begin{array}{l}\text { Category } 5 \text { - } \\
\text { St. John/St. Thomas } \\
\text { Category } 5 \text { - St. Croix }\end{array}$ & $\begin{array}{l}\text { Yes } \\
\text { Yes }\end{array}$ \\
\hline
\end{tabular}




\begin{tabular}{|c|c|c|}
\hline \multicolumn{3}{|c|}{$\begin{array}{l}\text { Table 3: } \\
\text { Seventeen } 2017 \text { Atlantic hurricane basin named tropical cyclones: } \\
\text { Impacts on } 29 \text { Caribbean Region Small Island Developing States (SIDS) }\end{array}$} \\
\hline $\begin{array}{l}\text { Tropical } \\
\text { Cyclone }\end{array}$ & $\begin{array}{l}\text { Caribbean Region Small Island Developing } \\
\text { States (SIDS) impacted }\end{array}$ & $\begin{array}{l}\text { Highest classification category } \\
\text { experienced for each of the } \\
\text { affected SIDS }\end{array}$ \\
\hline T.S. Arlene & \multicolumn{2}{|c|}{ No impacts from 2017 Atlantic tropical cyclones on Caribbean SIDS } \\
\hline T.S. Bret & $\begin{array}{l}\text { Grenada } \\
\text { Trinidad and Tobago }\end{array}$ & $\begin{array}{l}\text { Tropical Storm } \\
\text { Tropical Storm }\end{array}$ \\
\hline T.S. Cindy & \multicolumn{2}{|c|}{ No impacts from 2017 Atlantic tropical cyclones on Caribbean SIDS } \\
\hline T.S. Don & $\begin{array}{l}\text { Grenada } \\
\text { Saint Vincent and the Grenadines } \\
\text { Trinidad and Tobago }\end{array}$ & $\begin{array}{l}\text { Tropical Storm } \\
\text { Tropical Storm } \\
\text { Tropical Storm }\end{array}$ \\
\hline T.S. Emily & \multicolumn{2}{|c|}{ No impacts from 2017 Atlantic tropical cyclones on Caribbean SIDS } \\
\hline Franklin & Belize & Tropical Storm \\
\hline Gert & \multicolumn{2}{|c|}{ No impacts from 2017 Atlantic tropical cyclones on Caribbean SIDS } \\
\hline Harvey & $\begin{array}{l}\text { Barbados } \\
\text { Saint Lucia } \\
\text { Saint Vincent and the Grenadines }\end{array}$ & $\begin{array}{l}\text { Tropical Storm } \\
\text { Tropical Storm } \\
\text { Tropical Storm }\end{array}$ \\
\hline Irma & $\begin{array}{l}\text { Anguilla } \\
\text { Antigua and Barbuda } \\
\text { Bahamas } \\
\text { British Virgin Islands } \\
\text { Cuba } \\
\text { Dominican Republic } \\
\text { Guadeloupe } \\
\text { Haiti } \\
\text { Montserrat } \\
\text { Puerto Rico } \\
\text { Saint Kitts and Nevis } \\
\text { Sint Maarten } \\
\text { Turks and Caicos Islands } \\
\text { U.S. Virgin Islands (St. John, St. Thomas) }\end{array}$ & $\begin{array}{l}\text { Category } 5 \text { Hurricane } \\
\text { Category } 5 \text { Hurricane } \\
\text { Tropical Storm } \\
\text { Category } 5 \text { Hurricane } \\
\text { Category } 4 / 5 \text { Hurricane } \\
\text { Tropical Storm } \\
\text { Tropical Storm } \\
\text { Tropical Storm } \\
\text { Tropical Storm/ } \\
\text { Category } 1 \text { Hurricane } \\
\text { Category } 5 \text { Hurricane } \\
\text { Category } 5 \text { Hurricane } \\
\text { Category } 5 \text { Hurricane } \\
\text { Category } 5 \text { Hurricane }\end{array}$ \\
\hline Jose & $\begin{array}{l}\text { Anguilla } \\
\text { Antigua and Barbuda } \\
\text { Sint Maarten }\end{array}$ & $\begin{array}{l}\text { Tropical Storm } \\
\text { Tropical Storm } \\
\text { Tropical Storm }\end{array}$ \\
\hline Katia & \multicolumn{2}{|c|}{ No impacts from 2017 Atlantic tropical cyclones on Caribbean SIDS } \\
\hline Lee & \multicolumn{2}{|c|}{ No impacts from 2017 Atlantic tropical cyclones on Caribbean SIDS } \\
\hline
\end{tabular}

Table 3 continued: 


\begin{tabular}{|l|l|l|}
\hline Maria & Anguilla & Tropical Storm \\
& Antigua and Barbuda & Tropical Storm \\
& Bahamas & Tropical Storm \\
& Barbados & Tropical Storm \\
& British Virgin Islands & Tropical Storm \\
& Dominica & Category 5 Hurricane \\
& Dominican Republic & Tropical Storm \\
& Guadeloupe & Category 5 Hurricane \\
& Martinique & Tropical Storm \\
& Montserrat & Tropical Storm \\
& Puerto Rico & Category 4/5 Hurricane \\
& Saint Kitts and Nevis & Tropical Storm \\
& Saint Lucia & Tropical Storm \\
& Sint Maarten & Tropical Storm \\
& Turks and Caicos Islands & Category 3 Hurricane \\
& U.S. Virgin Islands (St. Croix) & Category 5 Hurricane \\
\hline Nate & Cuba & Tropical Storm \\
\hline Ophelia & No impacts from 2017 Atlantic tropical cyclones on Caribbean SIDS \\
\hline T.S. Philippe & Bahamas & Tropical Storm \\
& Cuba & Tropical Storm \\
\hline T.S. Rina & No impacts from 2017 Atlantic tropical cyclones on Caribbean SIDS \\
\hline
\end{tabular}




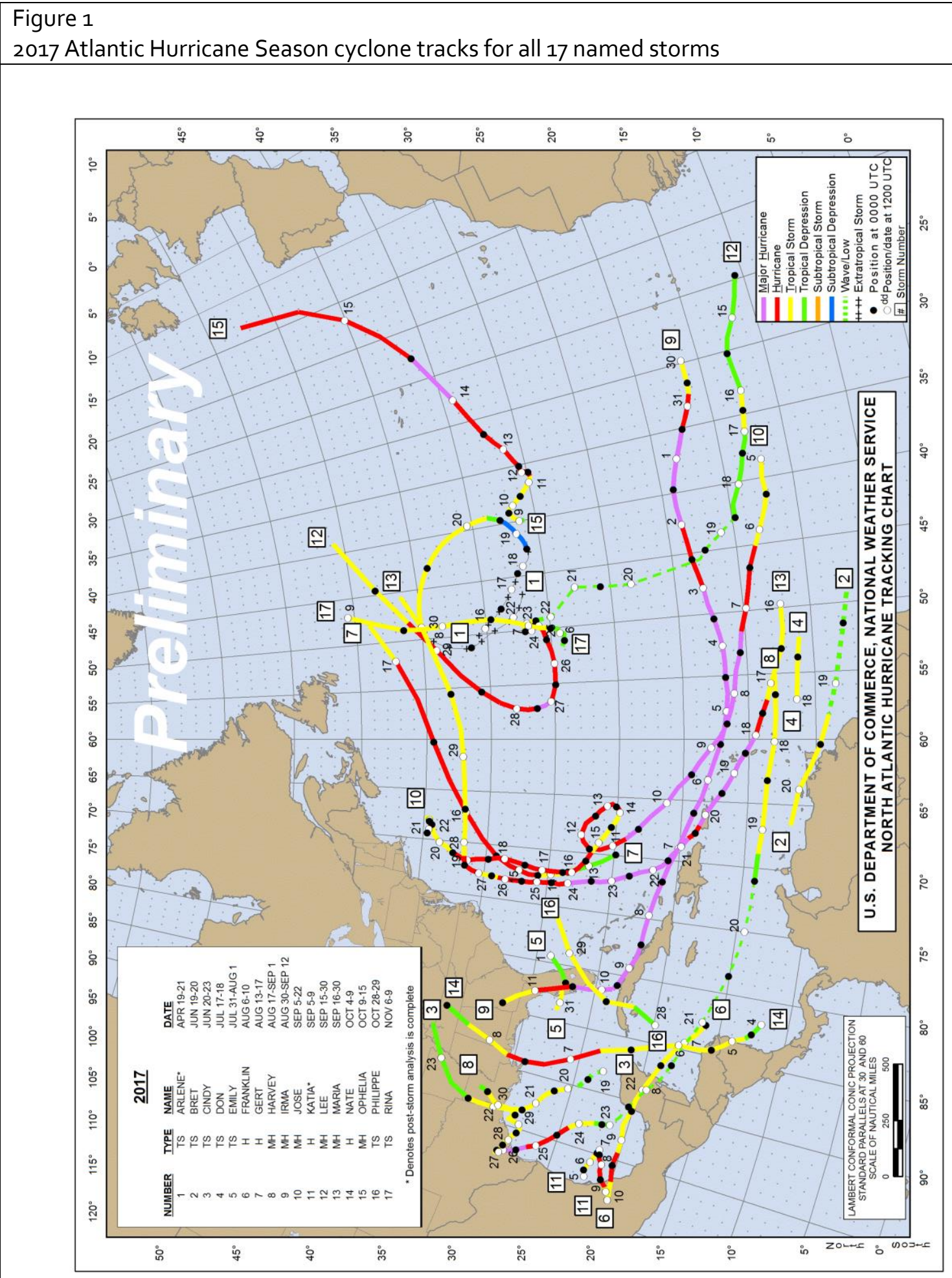




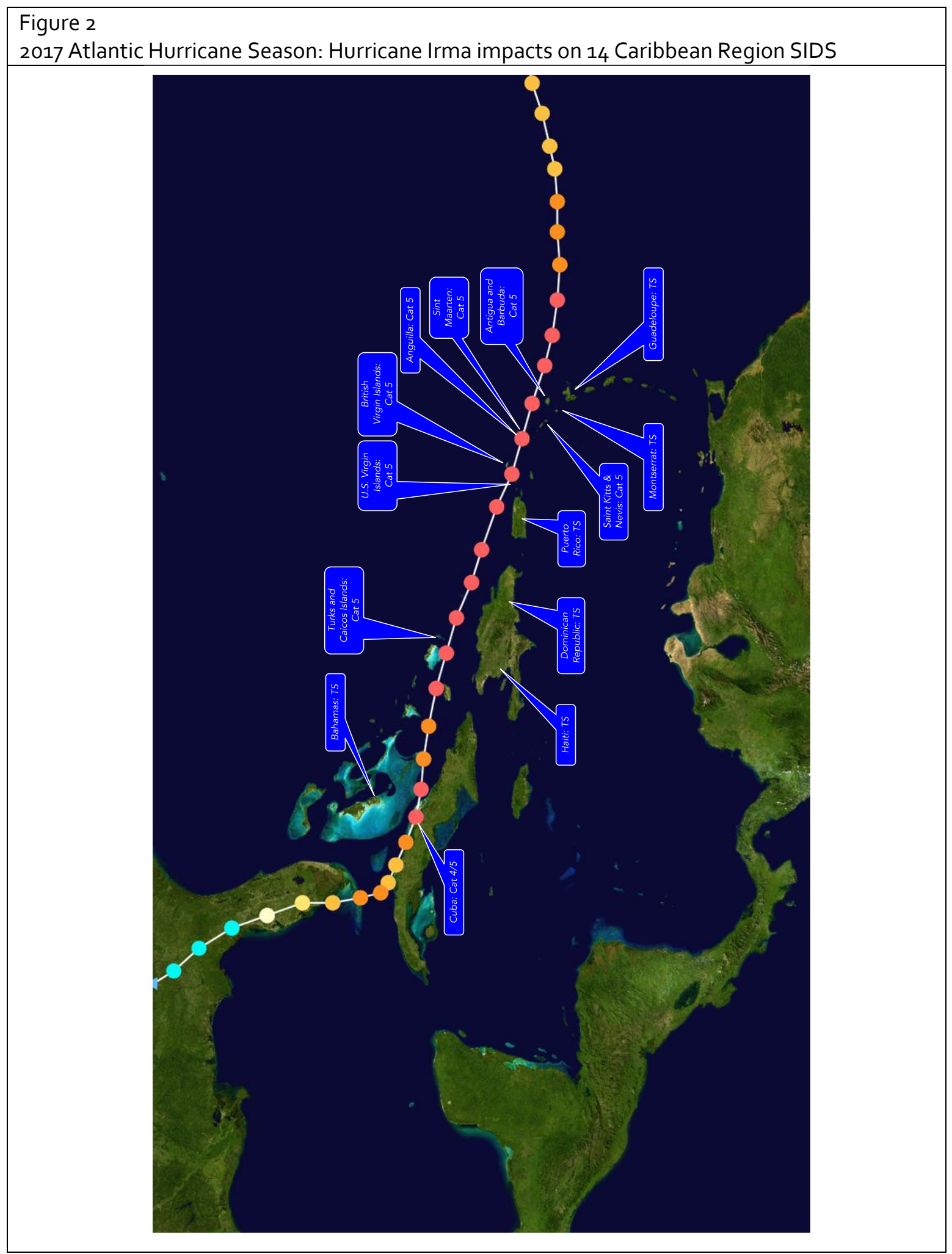

Figure 3 


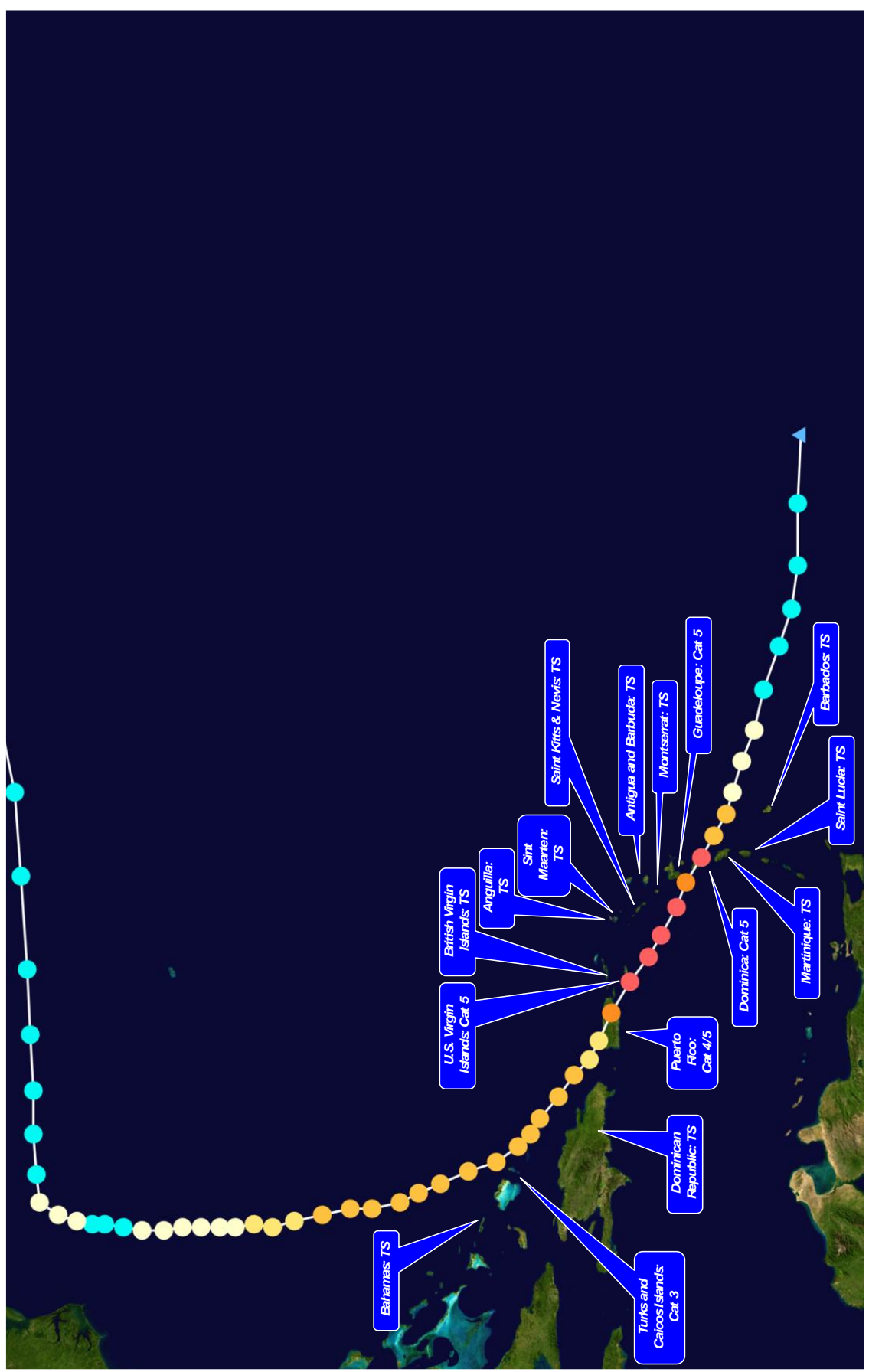

